\title{
WOJCIECH STANKIEWICZ
}

Olsztyn

\section{Budżet Unii Europejskiej - kierunki ewolucji systemu finansowania $w$ aspekcie nowej perspektywy finansowej 2007-2013}

Unia Europejska, pomimo że jest organizacją międzynarodową, w ramach pogłębiającej się integracji, coraz bardziej zaczyna przypominać działaniem i strukturą państwo federacyjne. Jest jedyną organizacją międzynarodową na świecie dysponującą tak szerokimi uprawnieniami wobec członków oraz znacznym rocznym budżetem (ok. 100 mld euro). Wraz ze wzrostem liczby państw członkowskich i zwiększającym się zakresem działania UE, coraz częściej dochodzi do coraz większych rozbieżności pomiędzy oczekiwaniami państw członkowskich, a możliwościami finansowymi UE.

Celem pracy jest nie tylko zaprezentowanie sytemu budżetu Unii Europejskiej, lecz ponadto ukazanie jego gospodarczego i strategicznego znaczenia w ujęciu globalnym. Założeniem jest przedstawienie instytucji odpowiedzialnych za inicjowanie i przygotowanie projektu budżetu oraz odniesienie do dostępności środków finansowych w ramach nowej Perspektywy Finansowej na lata $2007-2013^{1}$. Zamierzeniem autora jest zademonstrowanie struktury wydatków UE oraz priorytetów rozwojowych wspieranych poprzez transfer środków finansowych z budżetu ogólnego.

Hipotezą badawczą niniejszej pracy jest twierdzenie, że od budżetu, jakim dysponuje Unia Europejska, zależy skuteczność działania, potencjał rozwojowy oraz stabilność organizacyjno-prawna organizacji. Środki finansowe kierowane do państw członkowskich są wielką szansą na rozwój i narzędziem służącym niwelowaniu dysproporcji gospodarczych istniejących pomiędzy regionami UE.

W celu rozwiązania hipotezy postawiono następujące pytania badawcze:

1. W jaki sposób źródła finansowania budżetu Wspólnoty Europejskiej odzwierciedlają zasadę międzyrządowego i ponadnarodowego charakteru Unii Europejskiej?

2. Dlaczego budżet europejski cechuje istotne znaczenie polityczne?

3. Jak struktura wydatków budżetowych zabezpiecza zobowiązania wynikające z ram instytucjonalno-prawnych Unii Europejskiej?

4. Jakie instytucje i w jaki sposób odpowiadają za tworzenie, realizację oraz monitorowanie budżetu UE?

5. W jakich kierunkach ustalane są priorytety Perspektywy Finansowej Unii Europejskiej?

6. Dlaczego ogólne założenia budżetu ogólnego obejmują w ramach Perspektywy Finansowej okres 6 lat?

1 L. Oręziak, Perspektywy finansowania 2007-2013 - kierunki ewolucji systemu finansowania Unii Europejskiej, „Bank i Kredyt” 2004, R. 35, nr 7, s. 4-14. 
W badaniu zagadnienia zastosowano metodę analizy systemowej, metodę komparatystyczną (porównawczą), metodę analizy decyzyjnej, metodę analizy instytucjonalno-prawnej oraz analizy historycznej.

\section{Ewolucja systemu finansowego Unii Europejskiej}

W 1967 r. w wyniku utworzenia wspólnych organów naczelnych i zarządzających, połączono budżety Europejskiej Wspólnoty Gospodarczej, Euratomu oraz budżet administracyjny Europejskiej Wspólnoty Węgla i Stali (EWWiS), tworząc Wspólnoty Europejskie. Ustalone przez sygnatariuszy kierunki polityk, podejmowane działania w zakresie zintegrowania Europy Zachodniej były finansowane ze stworzonego budżetu ogólnego, zasilanego składkami Państw Członkowskich².

Harmonijny rozwój gospodarczy, zbliżenie ekonomiki państw członkowskich, a z czasem stworzenie swobodnego sytemu przepływu towarów wymagał wielu nakładów finansowych na realizację wyznaczonych celów. Powodzenie w realizacji strategii integracji europejskiej, w ujednoliceniu rozwoju poszczególnych regionów UE zależało od stabilnej współpracy Państw tworzących Wspólnoty Europejskie. Analizując system składkowego zasilania budżetu, można stwierdzić, że nie sprzyjał on harmonizacji działań w ustalonych unijnych priorytetach rozwojowych. Ponadto generował, możliwość wpływania na realizowane przez państwa członkowskie polityki i działania w sposób jednokierunkowy ${ }^{3}$.

Od początku lat 60 . ustalono, iż system finansowy będzie rozwiązaniem przejściowym, dopóki nie zostanie dokonana harmonizacja polityki rolnej, gospodarczej, celnej umożliwiająca zastosowanie odmiennych rozwiązań w zakresie finansowania wspólnego - z założenia - budżetu ${ }^{4}$.

Podczas obrad Rady Europejskiej w Luksemburgu w 1970 roku, decyzją z dnia 21 kwietnia 1970 r. przyjęto system środków własnych finansujący budżet Wspólnot ${ }^{5}$. Decyzja Rady oznaczała zaprzestanie poboru składek do budżetu przez poszczególne państwa członkowskie. Przyjęty przez Radę Europejską system finansowany zakładał, jako główne źródła finansowania, wpływy z tytułu opłat celnych, opłat cukrowych oraz podatków rolnych. Powyższe źródła finansowe nazwano tradycyjnymi środkami własnymi (ang. Traditional Own Resources - TOR).

W związku z problemami państw członkowskich z wprowadzeniem ujednoliconej podstawy podatku VAT, początkowo tylko TOR stanowiły główne źródło finansowania budżetu Wspólnot. Wpłaty z tytułu podatku VAT ustabilizowano w 1979 roku, kiedy państwa członkowskie zharmonizowały i ujednoliciły normalizacje prawne w zakresie poboru podatku VAT ${ }^{6}$.

2 L. Oręziak Finanse Unii Europejskiej, Wyd. Naukowe PWN, Warszawa 2005, s. 27.

3 K. Michałowska-Gorywoda, Unia Europejska, Wyd. Naukowe PWN, Warszawa 1998, s. 16.

4 Ibidem, s. 18.

5 Dziennik Urzędowy Wspólnot Europejskich L94/23, http://eur-lex.europa.eu/LexUriServ/site/pl/dd/01/01/31970D0244PL.pdf.

${ }^{6}$ Ibidem, s. 29. 
Ustalony system finansowania wraz z rozwojem integracji gospodarczej nie sprostał rosnącym potrzebom wspólnotowym. Powód stanowiło kilka aspektów, między innymi fakt, iż w wyniku kryzysu gospodarczego, jaki dotknął państwa członkowskie na początku lat 80., zwłaszcza w sektorze rolnym, nastąpiło zmniejszenie wpływów z tytułu opłat celnych, podatku rolnego i opłat cukrowych. Zmniejszające się wpływy z TOR oraz mniejsze dochody podatkowe, ze względu na słabe wyniki gospodarcze, zmniejszyły transfery finansowe do budżetu ogólnego Wspólnot. W wyniku zwiększania wydatków głównie w zakresie wsparcia Wspólnej Polityki Rolnej oraz rozszerzenia Wspólnot o inne kraje powstało zagrożenie deficytu budżetu ${ }^{7}$.

Od początku lat 80. rząd Wielkiej Brytanii podjął konsekwentne i zdecydowane starania o obniżenie wpłat dokonywanych do budżetu ogólnego Wspólnot. W uzasadnieniu starań wskazywano na znaczną dysproporcję między sumami wnoszonymi przez Wielką Brytanię do budżetu z tytułu ceł, opłat wyrównawczych i VAT a dochodami otrzymywanymi z budżetu, zwłaszcza w zakresie wspólnej polityki rolnej.

Na posiedzeniu Rady Europejskiej w czerwcu 1984 roku w Fontainebleau podjęto decyzję o podniesieniu maksymalnej stopy procentowej stosowanej do określania wysokości wpłat od podatku VAT do wysokości 1,4\% oraz wprowadzenie korekty wysokości wpłat Wielkiej Brytanii, tzw. „rabatu brytyjskiego"8.

W wyniku deficytu w budżecie ogólnym, powstałym po obniżeniu składek członkowskich Wielkiej Brytanii na obradach Rady Europejskiej w Brukseli w 1988 roku ustalono założenia reformy finansów wspólnotowych. Wprowadzono dodatkowe, nowe źródło finansowania budżetu, określane w literaturze ekonomicznej „,czwartym źródłem" (ang. fourth source) ${ }^{9}$, stanowiące wynik udziału Produktu Narodowego Brutto gospodarki danego kraju członkowskiego w stosunku do Produktu Narodowego Brutto Wspólnot Europejskich. Od tego momentu znaczenie bezpośrednich wpłat państw członkowskich do budżetu Wspólnot stale rosło. Współcześnie 60\% dochodów budżetowych pochodzi z tzw. „czwartego źródła”10.

Przy kształtowaniu zasobów własnych Wspólnot istotne znaczenie miało to, że maksymalny poziom wydatków wspólnot nie powinien przekraczać określonego pułapu na dany rok. Reforma finansów wspólnotowych wprowadziła od 1988 r. planowanie wydatków, dokonywanych w skali roku na poziomie nie większym niż $1,15 \%$ Produktu Narodowego Brutto całej Wspólnoty. Jednocześnie na mocy Decyzji Rady Europejskiej z 24 czerwca 1988 r. ${ }^{11}$ zmniejszono podstawę naliczania jednolitej stawki VAT. Przyjęto zasadę, iż podstawa liczona przez państwa w jednakowy sposób nie przekroczy 55\% PNB danego kraju. Umożliwiony bardziej sprawiedliwy niż poprzed-

${ }^{7}$ L. Oręziak, System finansowy Wspólnot Europejskich, w: E. Kawecka-Wyrzykowska, E. Sosnowiec, Unia Europejska, Wyd. Instytut Koniunktur i Cen Handlu Zagranicznego, Warszawa 2005, s. 330 .

${ }_{8}$ M. Cieślukowski, Budżet Unii Europejskiej, Wydawnictwo Akademii Ekonomicznej w Poznaniu, Poznań 2004, s. 56.

9 Dyrektywa Rady 89/130/EWG (DzUrz WE L 49/89) źródło: strona internetowa eur-lex.europa.eu.

${ }^{10}$ Ibidem, s. 58.

11 Decyzja Rady 88/376/WE z 24.06.1988 r. (DzUrz WE L 185/88) źródło: strona internetowa eur-lex.europa.eu. 
nio mechanizm pozyskiwania dochodów do budżetu Wspólnot, wynikał z faktu, że kraje słabsze ekonomicznie poświęcają na konsumpcję większą część swojego PNB niż kraje bogate ${ }^{12}$.

Po dokonanej reformie w 1988 r., w następnych latach dalej ograniczano rolę podatku VAT jako źródła finansowania budżetu UE oraz zwiększano stopniowo maksymalny poziom wydatków z budżetu, aż do obecnego 1,27\% PNB. Reformy te przyniosły pożądane efekty i w latach 90. sytuacja budżetu UE została ustabilizowana.

Według Leokadii Oręziak, wielkość dochodów budżetu ogólnego Wspólnot w latach 1971-2006 zwiększyła się ponad czterdziestokrotnie (2,33 mld ECU do 97,5 mld euro). Znaczącej zmianie uległa struktura źródeł finansowanego budżetu oraz udział procentowy transferów finansowych z poszczególnych źródel ${ }^{13}$.

Przedstawiona poniżej analiza źródeł finansowania budżetu Unii Europejskiej, obrazuje, iż ukształtowany system finansowania budżetu Wspólnoty Europejskiej odzwierciedla zasadę międzyrządowego i ponadnarodowego charakteru Unii Europejskiej.

Współcześnie cła rolne oraz składki cukrowe są najmniej znaczącym źródłem dochodów budżetu ogólnego. Opłaty rolne wynikają z organizacji rynku rolnego Unii oraz realizacji Wspólnej Polityki Rolnej. W systemie prawnym UE wyróżnia się następujące opłaty rolne m.in.:

- opłaty rolne nakładane na importowane produkty rolne, objęte wspólnotową regulacją rynku, pochodzące z państw trzecich;

- opłaty cukrowe nakładane na spółki cukrowe, które mają na celu rekompensatę unijnych działań regulujących rynek cukru oraz kosztów magazynowania ${ }^{14}$.

Kolejnym środkiem wpłacanym przez wszystkie państwa członkowskie do budżetu Unii Europejskiej są cła pobierane przy imporcie towarów z państw trzecich. Aktualnie w ramach unii celnej stosowana jest Wspólna Taryfa Celna, którą reguluje się wysokość ceł na towary importowane do UE. Wysokość stawek celnych ustalana jest przez Unię Europejską, a nie indywidualnie przez poszczególne państwa członkowskie. Ponadto zostały zniesione cła w handlu pomiędzy państwami członkowskimi ${ }^{15}$.

Ustalony system umożliwia rozwój gospodarczy poprzez swobodny przepływ towarów i usług w ramach Unii Europejskiej. W zamian za pobieranie ceł wspólnotowych każde państwo może zatrzymać $25 \%$ pobranych cel, jako koszt utrzymania administracji celnej. 75\% pobranych ceł musi być przekazana do budżetu ogólnego Unii. Udział „tradycyjnych środków własnych” (TOR) w finansowaniu budżetu Unii Europejskiej systematycznie spadał, w 1988 r. wynosił prawie 30\%, a współcześnie kształtuje się na poziomie ok. $12 \%$ budżetu ogólnego.

Stanowiące przez niemalże 20 lat najważniejsze źródło dochodów budżetu UE wpływy z tytułu podatku VAT stanowią aktualnie jedynie $25 \%$ dochodów budżeto-

12 L. Oręziak, op. cit., s. 337.

13 L. Oręziak Polityka budżetowa, czasopismo naukowe Narodowego Banku Polskiego „Bank i Kredyt”, lipiec 2005, nr 7, s. 4; T. Uryszek Struktura budżetu Wspólnot Europejskich, „Acta Universitatis Lodziensis. Folia Oeconomica” 2004, z. 181, s. 237-244.

${ }^{14}$ C. Kosikowski, Prawo finansowe w Unii Europejskiej $i w$ Polsce, Lexis Nexis, Warszawa 2005, s. 6.

${ }^{15}$ L. Oręziak, Rynek finansowy Unii Europejskiej, Bibliotek Bankowca, Twigger, Warszawa 1999, s. 41. 
wych. Ukształtowany sposób wyliczania wpłat jest skomplikowany, gdyż wielkość jednolitej stawki jest ustalana poprzez odjęcie, od podstawowej stawki maksymalnej, „zamrożonej stawki rabatu brytyjskiego". „Zamrożoną stawkę rabatu brytyjskiego" wylicza Komisja Europejska, przy uwzględnieniu, że: Wielka Brytania nie uczestniczy w finansowaniu swojego rabatu, a udział Austrii, Niemiec, Holandii i Szwecji w finansowaniu rabatu brytyjskiego jest zmniejszony.

Mechanizm korekty składki Wielkiej Brytanii do budżetu Unii Europejskiej staje się coraz większym problemem w dalszej reformie systemu finansowania. Rabat polega na zwrocie Wielkiej Brytanii 66\% różnicy pomiędzy procentowym udziałem kraju w płatnościach VAT a procentowym udziałem w wypłatach z budżetu UE, odniesionej do całości wypłat unijnych. Rabat jest udzielany poprzez obniżenie podstawy VAT (ang. VAT base) Wielkiej Brytanii ${ }^{16}$.

Różnica finansowa spowodowana „rabatem brytyjskim” jest pokrywana przez pozostałe państwa członkowskie. Na mocy decyzji z Berlina z 1999 roku Niemcy, Austria, Szwecja i Holandia wpłacają jedynie $25 \%$ obowiązującej kwoty. Decyzja o obniżeniu kwoty spowodowana była stale występującą różnicą między wpłatami do budżetu ogólnego wnoszonymi przez dany kraj a wypłatami netto z budżetu oraz w konsekwencji wyłonieniem się w obrębie Unii Europejskiej dwóch grup krajów: tzw. płatników netto oraz beneficjentów netto ${ }^{17}$.

Początkowo największymi płatnikami netto były Wielka Brytania oraz Niemcy, następnie dołączyły Austria, Holandia, Szwecja. Znaczny wkład wyżej wymienionych państw w finansowanie budżetu zwłaszcza w ramach podatku VAT z powodu wysokiego Produktu Narodowego Brutto postulowany był jako niesprawiedliwy, gdyż kraje te otrzymywały niewielkie kwoty wsparcia z tytułu członkowstwa w UE. Największymi beneficjentami netto w kategoriach absolutnych były Hiszpania, Grecja, Portugalia i Irlandia, które w wyniku niskiego PNB wpłacały niskie kwoty składkowe, otrzymując znaczne dotacje UE zwłaszcza dla sektora rolnego. Trzy najbogatsze kraje Belgia, Dania i Luksemburg, znalazły się również w grupie beneficjentów netto. Belgia i Dania z powodu otrzymywania znacznych środków związanych ze Wspólną Polityką Rolną, a Luksemburg dotowany z racji umiejscowienia siedzib niektórych instytucji Unii Europejskiej $^{18}$.

Pozycja beneficjenta netto, z punktu widzenia kraju „biorcy” jest uprzywilejowana, gdyż pomimo opłacania składek do budżetu ogólnego, bilans finansowy kształtuje się dodatnio, w wyniku wpływów do budżetu krajowego środków finansowych z UE. „Rabat brytyjski" oraz przyznane Niemcom, Austrii Szwecji i Holandii ulgi w płatnościach są przedmiotem nieustannych dyskusji, a nierzadko kontrowersji i konfliktów międzyrządowych poszczególnych państw członkowskich.

Należy postawić pytanie, jaka powinna być relacja środków otrzymywanych z budżetu do sumy wnoszonych przez dany kraj wpłat? Czy dokonywane wpłaty powinny być równoważne, w odniesieniu do każdego kraju, z wypłatami na jego rzecz? Zgodnie z przyjętą ogólnie obowiązującą w ramach UE zasadą pomocniczości i solidarności,

16 L. Oręziak, op. cit., Finanse Unii Europejskiej, s. 33.

17 Ibidem, s. 38

18 J. Kaczmarek, Unia Europejska. Rozwój i zagrożenia, ATLA2, Wrocław 2001, s. 36. 
kraje słabsze powinny otrzymywać ze wspólnego budżetu odpowiednio większe kwoty, niż do niego wnoszą. W ten sposób, uzyskując wsparcie finansowe dla rozwoju gospodarczego oraz przekształceń strukturalnych w gospodarce, mają szansę zmniejszyć dysproporcję gospodarczą z innymi krajami Unii Europejskiej.

Prowadzona polityka finansowa Unii Europejskiej uwzględnia powyższą zasadę, jednakże analizując kwestię tzw. „rabatu brytyjskiego” jest co najmniej kontrowersyjnym fakt, że w praktyce główny ciężar „rabatu brytyjskiego” ponoszą najbiedniejsze kraje Unii. Od wielu lat większość państw członkowskich wskazuje, że Wieka Brytania nie ma podstaw ekonomicznych do korzystania z mechanizmu korekcyjnego, ponieważ wiele innych państw o podobnej strukturze gospodarki uiszcza pełne składki ${ }^{19}$.

Środki finansowe z tytułu bezpośrednich wpłat państw członkowskich (tzw. ,czwarte źródło") stanowią odzwierciedlenie zastosowania zasady międzyrządowego i ponadnarodowego charakteru Unii Europejskiej. Z racji największego procentowo udziału, (60\% środków finansowych budżetu) aktualnie stanowią najważniejsze źródło finansowania działalności Unii. Wszystkie państwa członkowskie dokonują wpłaty, uiszczając jednakowy procent od Produktu Narodowego Brutto. Stawka jednolita stanowi wyrażony w procentach stosunek niepokrytych potrzeb budżetu ogólnego do sumy Produktu Narodowego Brutto UE. Komisja Europejska co roku ustala stawkę obowiązująca dla wszystkich państw członkowskich. Poziom wpłat uzupełnia brakujące dochody budżetowe, spowodowane niewystarczającymi wpływami z tytułu TOR i VAT, dlatego w literaturze określane jest oprócz tzw. „czwartego źródła” tzw. „źródłem uzupełniającym" (ang. topping up). Wprowadzenie powyższego źródła spowodowało przede wszystkim ustabilizowanie finansów UE oraz pozwoliło na stopniowy wzrost budżetu w średnim okresie, przy zachowaniu limitu wydatków na określonym poziomie. Składka od PNB pozwala na bardziej sprawiedliwe obciążenie państw członkowskich, proporcjonalne do ich potencjału gospodarczego ${ }^{20}$.

Pozostałe dochody stanowią ok. $3 \%$ dochodów budżetu i pochodzą z podatków od wynagrodzeń funkcjonariuszy instytucji Wspólnot, odsetek z tytułu zwłoki w płatnościach na rzecz budżetu ogólnego Unii Europejskiej, nadwyżek finansowych nagromadzonych w poprzednich latach.

Budżet ogólny musi sprostać wielu obowiązującym regułom, w ramach instytucjonalno-prawnych Unii Europejskiej ${ }^{21}$. Stosowane zasady jedności, jednoroczności, uniwersalności, specjalizacji oraz równowagi odpowiadają stosowanym zasadom przy konstruowaniu budżetów krajowych ${ }^{22}$.

Zgodnie z zasadą jedności wszystkie dochody i wydatki ugrupowania muszą być unormowane kompleksowo w jednym, wspólnym budżecie. Budżet UE jest jednym, ogólnie obowiązującym dokumentem. Wyraźnie określa rodzaj wydatków sklasyfikowanych według charakteru i przeznaczenia ${ }^{23}$.

19 M. Cieślukowski, op. cit., s. 64.

20 L. Oręziak, op. cit., s. 72.

21 B. Niedzielski, Budżet ogólny Unii Europejskiej, „Sprawy Międzynarodowe” 2006, R. 59, nr 2, s. $99-109$.

22 Z. Brodecki, Finanse Acquis communautaire, Wyd. LexisNexis, Warszawa 2004, s. 21.

23 P. J. Maciejewski, System finansowy, bankowy i monetarny Unii Europejskiej, Wyższa Szkoła Finansów i Bankowości w Radomiu, Radom 2000, s. 20. 
Stosując zasadę jednoroczności - wszystkie unijne operacje budżetowe są wykonywane w ciagu jednego roku obrachunkowego, który obejmuje okres od 1 stycznia do 31 grudnia. W oparciu o zasadę uniwersalności, wszystkie wpływy służą finansowaniu wszystkich wydatków, dlatego państwa członkowskie nie mogą wpłacać do budżetu kwot, stanowiących, różnicę pomiędzy zobowiązaniami wobec Unii a sumą, która dany kraj otrzyma ze wspólnego budżetu. W myśl zasady specjalizacji wykorzystywanie środków finansowych budżetu ma przypisany i określony cel. Stosowanie powyższej zasady stanowi gwarancję zapewnienia właściwego wydatkowania środków finansowych, przejrzystość procesu tworzenia projektu ustawy budżetowej oraz wykonanie budżetu zgodne z wolą organu budżetowego ${ }^{24}$.

Zastosowanie zasady równowagi budżetowej oznacza, że budżet unijny musi być zrównoważony, tzn. suma środków finansowych z tytułu dochodów musi być równa sumie wydatków. Nie ma możliwości pokrywania deficytu poprzez zaciaganie kredytów lub pożyczek.

Budżet Unii Europejskiej od budżetów narodowych wyróżnia kilka cech. Przede wszystkim niespełnianie roli narzędzia polityki makroekonomicznej, gdyż bieżące dochody i wydatki muszą się równoważyć, czyli nie ma możliwości wykorzystania deficytu do stabilizowania gospodarki. Niedopuszczalne jest powstanie deficytu. Wszystkie wydatki zaplanowane na dany rok muszą być sfinansowane ze środków własnych UE, a wysokość wpłat państw członkowskich jest każdego roku dostosowywana do potrzeb budżetu. Mechanizm planowania w określony sposób wydatków budżetu, w oparciu o ramy wieloletniego programowania objętego wytycznymi Perspektywy Finansowej, nie zawsze funkcjonuje sprawnie i często dochodzi do napięć pomiędzy głównymi organami w kwestiach budżetowych, tj. Komisją Europejską, Parlamentem Europejskim i państwami członkowskimi ${ }^{25}$.

W celu zapanowania nad chaotycznym rozwojem finansów Unii i zwiększenia dyscypliny budżetowej, z początkiem lat 90. wprowadzono wieloletnie programowanie budżetowe, oparte na sześcioletnich planach finansowych tzw. „Perspektywach Finansowych", określających główne elementy budżetu UE w poszczególnych latach.

Tryb uchwalania Perspektywy Finansowej jest złożony i zajmuje prawie dwa lata. Jest przede wszystkim decyzją polityczną państw członkowskich dotyczącą kierunku rozwoju finansów publicznych UE na następne sześć lat. Perspektywa Finansowa jest przyjmowana jednomyślnie na specjalnie zorganizowanym szczycie wszystkich państw członkowskich. Państwa członkowskie nie posiadają pełnej dowolności w uchwalaniu wielkości budżetu UE na poszczególne lata. Istnieją dwa ograniczenia stanowiące jednocześnie podstawowe wielkości referencyjne przy projektowaniu budżetu ${ }^{26}$.

Pierwszym ograniczeniem, a zarazem kluczowym pojęciem dla budżetu UE, są środki na zobowiązania (ang. appropriations for commitments). Określają maksymalny pułap zobowiązań, jakie w danym roku budżetowym mogą zostać podjęte przez Unię Europejską. Zgodnie z artykułem 3 ustęp 2 Decyzji Rady Europejskiej z 29 wrze-

${ }^{24}$ Ibidem, s. 25.

25 M. Cieślukowski, op. cit., s. 79-80.

${ }^{26}$ Ibidem, s. 84. 
śnia 2000 roku w sprawie systemu środków własnych Wspólnot Europejskich ${ }^{27}$, środki na zobowiązania nie mogą przekroczyć w ciagu roku budżetowego maksymalnego pułapu 1,335\% Produktu Narodowego Brutto wszystkich państw członkowskich. Środki na zobowiązania obejmują zarówno zobowiązania jednoroczne, jak i wieloletnie, a ich wielkość nie musi dokładnie odzwierciedlać wysokości wypłat z budżetu w danym roku.

Drugim ograniczeniem wielkości budżetu są środki na płatności ,ang. appropriations for payments", określające wysokość faktycznych wydatków z budżetu w danym roku. Zgodnie z artykułem 3 ustęp 1 Decyzji Rady Europejskiej ${ }^{28}$, środki finansowe nie mogą przekroczyć w ciagu roku budżetowego maksymalnego pułapu 1,27\% Produktu Narodowego Brutto państw członkowskich. Zmiana ustalonych pułapów wymaga jednomyślnej decyzji wszystkich państw członkowskich. Dwa pojęcia „appropriations for commitments" $\mathrm{i}$, appropriations for payments" służą określaniu wielkości poszczególnych rozdziałów w budżecie.

Środki na zobowiązania (appropriations for commitments) mogą być wyższe od środków na płatności (appropriations for payments), a ich wielkość i wzajemne relacje należy rozpatrywać na przestrzeni kilku lat budżetowych. W niektórych latach środki na zobowiązania mogą przewyższać środki na płatności, jednakże w następnych latach proporcje muszą zostać odwrócone $\mathrm{w}$ celu pokrycia zobowiązań $\mathrm{z}$ lat poprzednich.

$1,27 \%$ PNB państw członkowskich stanowi maksymalny pułap środków własnych UE na dany rok, które mogą zostać wydatkowane. Powyższe wielkości środków na zobowiązania i płatności, stanowią górne granice referencyjne, których budżety na poszczególne lata nigdy nie osiagają. Faktyczna wielkość środków własnych, zebranych $\mathrm{w}$ danym roku od państw członkowskich, zawarta jest w budżecie w pozycji całkowite środki na płatności (ang. total appropriations for payments) i stanowi wartość niższą od wartości maksymalnej. Przeciętnie wielkość budżetu w poszczególnych latach wahają się w granicach 1-1,19\% PNB wszystkich państw $\mathrm{UE}^{29}$.

Różnica pomiędzy pułapami maksymalnymi a planowanymi wielkościami budżetów na poszczególne lata stanowi pewien margines bezpieczeństwa. W przypadku nieprzewidzianych wydatków, umożliwia powiększenie budżetu w danym roku o wydatki nie objęte we wcześniej przyjętych limitach budżetowych. Stwarza to możliwość ewentualnej korekty budżetu i dostosowania do planowanych działań, nawet gdy planowana wielkość budżetu może się okazać zbyt mała, aby sfinansować wszystkie zaplanowane wydatki ${ }^{30}$.

Potwierdzeniem wszystkich ustaleń podejmowanych przez państwa członkowskie w trakcie przyjmowania Perspektywy Finansowej stanowi porozumienie interinstytucjonalne (ang. Interinstitutional Agreement) pomiędzy Parlamentem Europejskim, Radą i Komisją w sprawie dyscypliny budżetowej i poprawy procedur budżetowych. Zawierany akt prawny Unii Europejskiej, którego stroną są wszystkie organy budżeto-

27 Decyzja Rady Europejskiej z dnia 29 września 2000 r. w sprawie systemu środków własnych Wspólnot Europejskich (2000/597/WE, Euratom), źródło: http://europa.eu.int/eur-lex/pl.

28 Decyzja Rady, ibidem.

29 L. Oręziak, Finanse Unii Europejskiej, op. cit., s. 73.

30 Ibidem, s. 74 
we tej organizacji, ma na celu zobowiązanie organów do przestrzegania postanowień Perspektywy Finansowej ${ }^{31}$.

Usankcjonowanie dokumentem porozumienia międzyinstytucjonalnego jest konieczne z uwagi na polityczny charakter Perspektywy Finansowej ustalanej tylko przez państwa członkowskie, w konsekwencji nie wiążąco dla innych organów budżetowych. Potwierdzenie ustaleń poprzez przyjęcie aktu prawnego, wiążącego wszystkie strony zapewnia, że w trakcie uchwalania kolejnych rocznych budżetów UE, wszystkie strony procesu będą zobligowane do przestrzegania ustalonych pułapów wydatków. Dokument jest zawsze zawierany na czas trwania danej Perspektywy Finansowej.

W „Interinstitutional Agreement” określono również wiele innych elementów istotnych z punktu widzenia procedury budżetowej. Po pierwsze ustalane są zasady dokonywania technicznych adaptacji Perspektywy Finansowej. Ściśle określone, szczegółowe zasady dostosowania rocznych budżetów UE do poziomu cen, tempa wzrostu gospodarczego, umożliwiają zmianę systemu budżetowego w sposób elastyczny. W „Interinstitutional Agreement" wskazano dodatkowo tryb zmiany Perspektywy Finansowej. Zmiany (zwiększenie) alokacji w poszczególnych rozdziałach wydatków mogą nastapić tylko w związku z nieprzewidzianymi wydarzeniami i tylko do wysokości maksymalnego pułapu tj. 1,27\% PNB dla środków na płatności. Nieprzewidziane wydatki najpierw powinny być finansowane $\mathrm{z}$ rezerw, a dopiero gdy środki finansowe są niewystarczające, może dojść do zmiany Perspektywy Finansowej ${ }^{32}$.

Każde zwiększenie środków Perspektywy Finansowej inicjowane jest propozycją przygotowaną przez Komisję Europejską i zatwierdzaną przez Radę i Parlament Europejski. Jeżeli zmiana ma dotyczyć kwoty większej niż 0,03\% PNB Unii Europejskiej, wówczas Rada musi działać jednomyślnie. Powstaje poważne ograniczenie, gdyż wiele państw pozostających płatnikami netto, trudno jest przekonać do zwiększania obciążeń finansowych na rzecz budżetu UE. W „Interinstitutional Agreement” zawarto podział wydatków na obowiązkowe i nieobowiązkowe oraz potwierdzono zasadę, że wszystkie wydatki UE muszą mieć podstawę prawną w postaci odpowiedniego aktu prawnego (Rozporządzenia, Dyrektywy lub Decyzji) ${ }^{33}$.

Podział budżetu unijnego na zobowiązania obligatoryjne i nieobligatoryjne stanowi cechę odróżniającą go od budżetów krajowych. Wśród wydatków obowiązkowych wyróżnia się te, które mają umożliwić Unii Europejskiej wywiązanie się z obowiązków wewnętrznych i zewnętrznych wynikających z traktatów lub aktów prawnych. Nieobowiązkowe zadania stanowią fundusze strukturalne, wydatki administracyjne oraz wydatki związane z polityką wewnętrzną.

Analizując strukturę wydatków budżetu Unii Europejskiej na przestrzeni lat, można zauważyć dywersyfikację, jednakże w dalszym ciąu najważniejsze znaczenie gospodarcze stanowią kwoty przeznaczone na cele rolnicze. Dotychczas, nie udało się w innych dziedzinach gospodarki, poza rolnictwem, wprowadzić wspólnej polityki zbliżonej za-

31 Z. Brodecki, op. cit., s. 76.

32 M. Cieślukowski, Znaczenie perspektywy finansowej w systemie budżetowym Wspólnot europejskich, w: Unia Europejska. Gospodarka polski na drodze do Unii Europejskiej, Zeszyty Naukowe Wyższej Szkoły Bankowej w Poznaniu, Poznań 2002, nr 15, s. 143-145.

33 Ibidem, s. 77. 
kresem do polityki rolnej. W przeciwnym razie zastosowanie podobnego rozwiązania np. w przemyśle, edukacji, transporcie czy badaniach naukowych, oznaczałoby konieczność, poza przekazaniem uprawnień narodowych na rzecz wspólnych organów UE, zapewnienie odpowiednio większych środków finansowych w budżecie ${ }^{34}$.

Wydatki na finansowanie Wspólnej Polityki Rolnej dokonywane są z Europejskiego Funduszu Orientacji i Gwarancji w Rolnictwie (ang. EAGGF - European Agriculture Guidance and Guarantee Funds) stanowiącego integralną część budżetu ogólnego. Z Sekcji Gwarancji Funduszu wydatkowane są środki na interwencję na rynku artykułów rolnych podlegających wspólnej organizacji. Wydatki służą przede wszystkim utrzymaniu określonego poziomu cen na rynku wewnętrznym UE, jak również pokryciu subsydiów dla eksporterów produktów rolnych na rynki krajów trzecich. Największa część wydatków dotyczy olejów, tłuszczów, mleka i produktów mlecznych oraz zbóż, wołowiny i cukru ${ }^{35}$.

W ramach Wspólnej Polityki Rolnej główne wydatki nastawione są na regulację rynku rolnego poprzez dopłaty bezpośrednie dla rolników, dopłaty do eksportu produktów rolnych do krajów trzecich, bezpośrednie wypłaty dla rolników związane z rodzajem ich działalności, na podstawie udokumentowanej wielkości produkcji. Od 1988 roku wspomagana finansowo jest również deprecjacja nowo tworzonych zapasów oraz połowa kosztów związanych z programem odłogowania ziemi rolnej. W ramach „Wydatków rolnych" określonych w budżecie UE, finansowane są również wydatki na wsparcie rybołówstwa oraz rozwój obszarów wiejskich ${ }^{36}$.

Na przestrzeni ostatnich lat Unia Europejska podjęła wiele działań mających na celu ograniczenie kosztów funkcjonowania WPR poprzez redukcję cen podstawowych produktów rolnych, zbliżając je do cen światowych oraz większe wspieranie działań mających na celu ograniczenie wielkości produkcji rolnej. Doprowadzono do znacznego zmniejszenia udziału wydatków na Wspólną Politykę Rolną w stosunku do wielkości budżetu (z 60\% w 1988 do ok. 45\% w 2003)

Wydatki na działania strukturalne stanowią drugą pod względem znaczenia grupe wydatków budżetu ogólnego. Działania finansują środki zgromadzone w ramach dwóch dużych funduszy unijnych: Funduszy Strukturalnych i Funduszu Spójności. Wysokość alokowanych środków stanowi ok. 40\% wydatków Unii Europejskiej. W przeciwieństwie do wydatków na rolnictwo, by móc skorzystać z funduszy państwa członkowskie muszą przedstawić właściwe programy wykorzystania środków finansowych oraz zapewnić odpowiedni poziom współfinansowania (od 20-60\% kwoty dofinansowania stanowią krajowe środki finansowe) $)^{38}$.

${ }^{34}$ M. Cieślukowski, op. cit., s. 66.

35 M. Cieślukowski, Kierunki reformy wydatków budżetowych Unii europejskiej, w: Ekonomiczne i prawne problemy racjonalizacji wydatków publicznych. Racjonalizacja wydatków publicznychuwarunkowania i instrumenty, Wydawnictwo Uniwersytetu Marii Curie-Skłodowskiej, Lublin 2005, t. I, s. 33.

36 J. Babiak, Fundusze Unii Europejskiej. Doświadczenia i perspektywy, Wyd. EMKA, Warszawa 2006, s. 11.

${ }^{37}$ M. Czerniejewska-Rutkowska, Europeizacja polityki fiskalnej-adaptacja państw członkowskich do ram budżetowych UE. Wnioski dla Polski, Centrum Europejskie Natolin, Warszawa 2003, s. 17.

38 W. Nicole, T. C. Salmon, Zrozumieć Unię Europejska, Książka i Wiedza, Warszawa 2002, s. 359. 
Ponad 90\% zaplanowanych środków przeznaczona jest na finansowanie Funduszy Strukturalnych, które stanowią: Europejski Fundusz Orientacji i Gwarancji w Rolnictwie utworzony w 1975 r., Europejski Fundusz Rozwoju Regionalnego - EFRR (ang. ERDF - European Regional Development Fund), powołany w 1960 r. Europejski Fundusz Społeczny EFS - (ang. ESF - European Social Fund) na podstawie art. 123 Traktatu ustanawiającego Europejską Wspólnotę Gospodarczą (1957), Fundusz Spójności powołany w 1994 r. na podstawie art. 130d wprowadzonego do TWE przez Traktat o Unii Europejskiej (obecnie art. 161), a także odgrywający marginalną rolę Finansowy Instrument Orientacji Rybołówstwa - FIOR (Financial Instrument for Fisheries Guidance) ${ }^{39}$.

Środki finansowe kierowane do krajów członkowskich w ramach wyżej wymienionych funduszy obejmują trzy podstawowe cele wsparcia: 1 - wspieranie rozwoju regionów, 2 - wspieranie zmian społecznych i ekonomicznych w regionach dotkniętych strukturalnymi problemami gospodarczymi, 3 - wspieranie walki z bezrobociem. Współcześnie w ramach nowej Perspektywy Finansowej ustalonej na lata 2007-2013 uwzględniono trzy dodatkowe cele zatytułowane: 1) konwergencja - zmniejszanie dysproporcji pomiędzy biednymi a bogatymi regionami; 2) konkurencyjność regionalna i zatrudnienie; 3) europejska współpraca terytorialna. Ustalenie wyżej wymienionych priorytetów oraz ich realizacja zgodnie z polityką budżetową przyczynia się do wzrostu gospodarczego oraz wyrównania poziomu rozwoju w całej Unii Europejskiej ${ }^{40}$.

Stopniowo, jednak w bardzo wolnym tempie, wzrasta w budżecie udział wydatków na finansowanie prac badawczo-rozwojowych (ok. 5\% wydatków budżetowych). Celem finansowania wydatków jest wspieranie działań nastawionych na wzmocnienie bazy naukowej i technologicznej Unii Europejskiej oraz poprawę międzynarodowej konkurencyjności. Wspierana jest współpraca z krajami trzecimi w sferze badań i rozwoju technologicznego. W ramach wydatków z budżetu ogólnego UE finansowane są działania wspierające ochronę konsumentów oraz rozwój działań kulturalnych ${ }^{41}$.

W budżecie ogólnym stopniowo rośnie udział wydatków na finansowanie działań zewnętrznych Unii Europejskiej (ok. 5\% wydatków). Działania obejmują różne formy współpracy z krajami trzecimi: pomoc finansową i techniczną, żywnościową, wspieranie działań na rzecz demokracji i obrony praw człowieka, działania na rzecz ochrony środowiska. Wsparciem finansowym objęto między innymi kraje byłego ZSRR, regionu Morza Śródziemnego, krajów rozwijających się Azji i Ameryki Łacińskiej, krajów Afryki, Karaibów i Pacyfiku. Fundusze pochodzące z budżetu stanowią coraz ważniejszy instrument pozwalający państwom członkowskim Unii na wspólną realizację priorytetowych celów polityki zagranicznej ${ }^{42}$.

Kolejną kategorią wydatków budżetowych jest finansowanie administracji Unii Europejskiej. Ok. 5\% budżetu ogólnego zabezpiecza środki finansowe na pensje dla pracowników, emerytury, utrzymanie budynków, publikacje dzienników urzędowych i innych dokumentów oraz finansowanie przedstawicielstw dyplomatycznych Unii Europejskiej w państwach trzecich ${ }^{43}$.

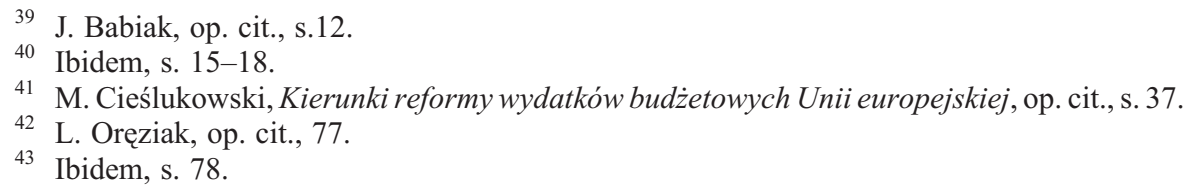


Budżet ogólny UE zabezpiecza ponadto środki finansowe na „wyrównania dla państw członkowskich" słabych gospodarczo, lecz uiszczających pełne składki członkowskie (np. Polska od momentu akcesji otrzymała 1 mld euro dodatkowych środków finansowych z tytułu ,wyrównań”. Ponadto w budżecie ogólnym UE w okresie obowiązywania Perspektywy Finansowej na lata 2000-2006 zabezpieczono środki na tzw. „pomoc przedakcesyjną” finansowanie członkowstwa nowych państw.

Cechą odróżniającą budżet UE od budżetów narodowych jest przedstawiony charakter systemu wydatkowania. Budżet Unii musi być zbilansowany, więc wielkość wpłat z państw członkowskich zostaje dostosowana do aktualnych potrzeb, nie można jednak zaplanować większych wydatków od przewidzianych w Perspektywie Finansowej. Coroczna debata dotyczy głównie uszczegółowienia wydatków systemu finansowania Wspólnoty ${ }^{44}$.

Oryginalność budżetu UE zapewnia wyodrębnienie określonych wydatków wspólnych dla wszystkich państw członkowskich, które tworzą system wydatków budżetowych. Budżet ogólny różni się od krajowych m.in. brakiem wydatków na edukację, służbę zdrowia i politykę socjalna, obsługę długu publicznego, transport, wsparcie handlu, promocję, policję czy wojsko.

Kwestie dotyczące finansowania działalności Unii Europejskiej często prowadzą do wielu kontrowersji i problemów oraz są tematem częstych dyskusji. Uchwalenie budżetu jest jednym z najważniejszych wydarzeń w roku.

Uzgadnianie Perspektywy Finansowej, w której określone są wielkości budżetów na poszczególne lata, nie zwalnia organów Unii Europejskiej od przygotowywania szczegółowych rocznych budżetów. Cała debata budżetowa w praktyce dotyczy tylko pewnych szczegółów dotyczących wydatków w poszczególnych rozdziałach oraz drobnych przesunięć i korekt, gdyż podstawowe wielkości budżetu oraz poszczególnych rozdziałów wynikają z obowiązującej w danym czasie Perspektywy Finansowej. Kwestia dochodów budżetowych nie wzbudza kontrowersji na tym etapie dyskusji, ponieważ maksymalna wielkość budżetu została ustalona. Głównymi instytucjami uczestniczącymi w corocznej procedurze uchwalania budżetu UE są Komisja, Rada i Parlament Europejski, jednak jedynie ostatnie dwa organy posiadają formalne prawo uchwalania budżetu. Podstawowe zasady procedury budżetowej określone są w art. 268-280 Traktatu o Wspólnocie Europejskiej ${ }^{45}$.

Podstawowe zadanie Komisji Europejskiej stanowi przygotowanie projektu budżetu. Pierwsze działanie ma na celu uaktualnienie limitów określonych w Perspektywie Finansowej na dany rok do bieżących wielkości makroekonomicznych. Perspektywa posługuje się kwotami opartymi na cenach z roku poprzedzającego jej przyjęcie. Komisja dostosowuje ustalone w Perspektywie wielkości do aktualnych cen w danym roku. Następnie zbierane są wstępne dane z poszczególnych Dyrekcji Generalnych Komisji dotyczące planowanych wydatków. Po przeprowadzonych pierwszych konsultacjach w ramach procedury przewidzianej w „Interinstitutional Agreement” pomiędzy wszystkimi organami budżetowymi, w kwietniu Komisja przyjmuje wstępny projekt budżetu.

44 Ibidem, s. 78-79.

45 Traktat ustanawiajacy Wspólnotę Europejska, tekst skonsolidowany (uwzględniający zmiany wprowadzone Traktatem z Nicei, Dziennik Urzędowy UE C 325 z 24 grudnia 2002 r.), źródło: http://prawo.lex.pl - polski serwer prawa. 
Zgodnie z przepisami traktatowymi Komisja objęta jest terminem do 1 sierpnia na przesłanie oficjalnego wstępnego projektu budżetu do Rady, w praktyce jednak do 15 czerwca. Jednocześnie projekt zostaje nieformalnie przesyłany we wszystkich językach UE do wszystkich organów budżetowych. Następnie Komisja zbiera uwagi oraz wnioski dotyczące projektu budżetu i dokonuje wymaganych poprawek ${ }^{46}$.

Po otrzymaniu wstępnego projektu budżetu Radę obowiązuje termin do 5 października na przyjęcie i przesłanie projektu do Parlamentu Europejskiego. W tym czasie zgodnie z postanowieniami Interinstitutional Agreement trwają trójstronne konsultacje pomiędzy Komisją, Radą i Parlamentem, dotyczące wydatków obowiązkowych. Pierwszy etap konsultacji przeprowadzany jest przy udziale odpowiedzialnego za budżet przedstawiciela Prezydencji (Rada), Przewodniczącego Komisji Budżetowej (Parlament) i Komisarza ds. budżetu. Następny etap konsultacji odbywa się przy udziale delegacji ze wszystkich trzech organów. Po wypracowaniu porozumienia w sprawie wydatków obowiązkowych Rada przyjmuje wstępny projekt budżetu. Przyjęcie projektu w Radzie następuje poprzez głosowanie większością kwalifikowaną. Jeżeli Radzie nie uda się przyjąć budżetu w terminie do 5 października wówczas Komisja i Parlament mają prawo pozwać Radę do Europejskiego Trybunału Sprawiedliwości za brak działania $^{47}$. Z uprawnienia skorzystano w 1987 roku, ale w związku z uchwalaniem budżetu na 1988 rok Trybunał postanowił nie wydawać orzeczenia w tej sprawie ${ }^{48}$.

Parlament w terminie 45 dni od daty wpływu projektu budżetu, ma za zadanie zajęcie stanowiska wobec przedłożonego projektu, jeżeli w tym czasie nie zgłosi poprawek, wówczas budżet zostaje przyjęty. Jeżeli Parlament podejmie decyzję o zgłoszeniu poprawek (a taka jest reguła) wówczas projekt wraz z poprawkami kierowany jest do ponownego rozpatrzenia przez Radę. Parlament uchwala poprawki do budżetu absolutną większością głosów podczas sesji plenarnej.

Rada w terminie 15 dni ustosunkowuje się do poprawek zgłoszonych przez Parlament. Jeżeli Rada nie zmieni żadnej z zaproponowanych poprawek, wówczas budżet zostanie przyjęty. W odniesieniu do poprawek zgłoszonych przez Parlament dotyczących wydatków nieobowiązkowych, Rada działając większością kwalifikowaną może podjąć decyzję o zmianie bądź odrzuceniu poprawek. Natomiast w odniesieniu do poprawek dotyczących wydatków obowiązkowych, jeżeli nie powodują ogólnego wzrostu obciążeń budżetu, Rada działając większością kwalifikowaną może dokonać zmiany. Jeżeli nie zostanie podjęta decyzja o zmianie, zgłoszona poprawka Parlamentu pozostaje w mocy. Odmiennie przedstawia się sytuacja w odniesieniu do poprawek dotyczących wydatków obowiązkowych powodujących wzrost obciążeń budżetu. Wobec takich propozycji Rada potwierdza zmiany, podejmując decyzję większością kwalifikowaną. Decyzje Rady dotyczące wydatków obowiązkowych podjęte w drugim czytaniu są ostateczne, chyba że Parlament odrzuci cały budżet ${ }^{49}$.

W drugim czytaniu Parlament pracuje nad wydatkami nieobowiązkowymi. W terminie 15 dni może dokonać ponownych zmian w odniesieniu do wydatków lub nie

\footnotetext{
46 L. Oręziak, Finanse Unii Europejskiej, op. cit., s. 83.

47 Ibidem, s. 85.

48 Ibidem, s. 86.

49 Ibidem, s. 90.
} 
zgłaszać żadnych uwag. Zgłoszone poprawki muszą być przyjęte przez parlamentarzystów, większością trzech piątych głosów. Drugie czytanie w Parlamencie kończy procedurę budżetową i Przewodniczący Parlamentu ogłasza przyjęcie budżetu. Jeśli Parlament nie przyjmie decyzji Rady dotyczącej wydatków obowiązkowych, wtedy następuje odrzucenie budżetu w całości (art. 272.8 Traktatu) ${ }^{50}$. Jeżeli budżetu nie uda się uchwalić przed rozpoczęciem nowego roku, wówczas obowiązuje zasada tzw. ,jednej dwunastej wydatków". Komisja Europejska ma prawo otrzymać kwotę równą jednej dwunastej wydatków przewidzianych $\mathrm{w}$ omawianym w danej chwili projekcie budżetu, w celu zapewnienia ciągłości funkcjonowania Unii Europejskiej do chwili uchwalenia budżetu.

Współcześnie roczne budżety UE są uchwalane z uwzględnieniem ram finansowych, określanych w Perspektywie Finansowej, która umożliwia podejmowanie wspólnych działań o dłuższym niż rok horyzoncie czasowym. Wydatki zawarte w Perspektywie Finansowej są podzielone na grupy. W odniesieniu do każdej z grup określany jest pułap na zobowiązania dotyczące wydatków w danym roku budżetowym. Wielkość wydatków określonych w obowiązującej w danym czasie perspektywie, jest corocznie aktualizowana z uwzględnieniem wzrostu cen oraz zmiany DNB (dochodu narodowego brutto) Unii Europejskiej.

Perspektywę Finansową od budżetów rocznych odróżnia określenie szczegółowości wydatków na poziomie limitów w odniesieniu do podstawowych grup, co daje pewną swobodę przy szczegółowym ustalaniu wysokości wydatków. W wieloletniej Perspektywie Finansowej oraz budżecie rocznym wspólne są ogólna klasyfikacja i układ grup wydatków, co ułatwia porównanie budżetu z postanowieniami Perspektywy.

Podstawą ustalenia Perspektywy Finansowej na lata 2000-2006 było przyjęcie w 1999 r. na Szczycie w Berlinie przez Rade Europejską dokumentu Agenda 2000 Komisja Europejska zawarła w nim propozycje reformy wspólnej polityki rolnej, zmian w finansowaniu rozwoju regionalnego, a także zasady finansowania procesu rozszerzenia Unii o nowe kraje członkowskie ${ }^{51}$.

Na lata 2000-2006 przeznaczono środki finansowe na politykę strukturalną w wysokości 0,46\% Produktu Narodowego Brutto Unii Europejskiej, a także dodatkowe przeznaczenie około 5\% środków budżetowych na rozwój obszarów wiejskich. Ogólnie na Fundusze Strukturalne i Fundusz Spójności przeznaczono w tym czasie 213 mld euro (37\% całego budżetu Wspólnoty). Około 45 mld euro z budżetu Unii zostało zarezerwowane w ramach pomocy przedakcesyjnej, w tym 7 mld euro na cele dostosowawcze do czasu wejścia do Wspólnoty i pełnej integracji. Przyjętym dokumentem Agenda 2000 wprowadzono istotną zmianę dotyczącą zmiany okresu programowania perspektyw finansowych z 6 lat (1994-1999) do 7 lat (2000-2006).

Prace nad nową Perspektywą Finansową na lata 2007-2013 rozpoczęły się już w 2004 r. Punktem wyjścia było przyjęcie przez Komisję Europejską komunikatu z dnia

50 Traktat ustanawiajacy Wspólnotę Europejska, op. cit.

51 Akty prawne Parlamentu Europejskiego i Rady dotyczqce Instrumentów Strukturalnych i Przedakcesyjnych na lata 2000-2006, Ministerstwo Gospodarki, Warszawa 2000 oraz Przedsięwzięcia strukturalno-polityczne 2000-2006, komentarze i zarzadzenia, Komisja Europejska, Luxembourg 2000. 
10 lutego 2004 r. Budowanie naszej wspólnej przyszłości - Wyzwania polityczne i środki budżetowe w rozszerzonej Unii (ang. Communication from the commission to the council and the European Parliament. Building our common Future Policy challenges and Budgetary means of the Enlarged Union 2007-2013) ${ }^{52}$ zawierającego projekt nowej Perspektywy Finansowej 2007-2013 $3^{53}$.

Rządy państw Unii Europejskiej w kwestii nowej Perspektywy Finansowej 2007-2013 osiągnęły porozumienie na szczycie Rady Europejskiej w grudniu 2005 r. Po długich negocjacjach, dotyczących m.in. procentu udziału unijnego budżetu w dochodzie narodowym brutto Wspólnoty, projekt nowej Perspektywy Finansowej na lata 2007-2013 został przyjęty 17 maja 2006 r. w ramach Międzyinstytucjonalnego Porozumienia $w$ sprawie dyscypliny budżetowej i poprawy procedury budżetowej pomiędzy Parlamentem Europejskim, Rada i Komisja Europejska ${ }^{54}$.

Wynegocjowany budżet stanowi 1,05\% DNB (dochodu narodowego brutto) Unii Europejskiej. Jest to procentowo mniej niż proponowała Komisja Europejska (1,14\%), jednakże więcej niż postulowały kraje płatnicy netto (1\%). Dla Polski porozumienie budżetowe przewiduje 89,6 mld euro w ciągu siedmiu lat, co po opłaceniu składek do budżetu UE oznacza netto około 60 mld euro. Najwięcej, bo aż 59,7 mld euro Polska może otrzymać w ramach Funduszy Strukturalnych i Funduszu Spójności na rozwój najbiedniejszych regionów, walkę z bezrobociem czy budowę infrastruktury. Ponad 24 mld euro przeznaczone zostało na wsparcie rolnictwa (w szczególności na dopłaty bezpośrednie i rozwój obszarów wiejskich), pozostałe środki finansowe skierowane będą na programy edukacyjne (m.in. Erasmus), naukowe oraz na cele związane z polityką sprawiedliwości i spraw wewnętrznych (m.in. ochrona granic i walka z terroryzmem). Nowa Perspektywa Finansowa na lata 2007-2013 zakłada debatę w kwestii rabatu brytyjskiego. Zgodnie z przyjętym dokumentem Instytucje Wspólnotowe powrócą do analizy ulgi w opłacaniu składek budżetowych stosowanej względem Wielkiej Brytanii w 2008/2009 r. podczas przeglądu ram finansowych.

W świetle nowej Perspektywy Finansowej 2007-2013 można zauważyć wyraźne przesunięcie priorytetów w stosunku do założeń Agendy 2000 (perspektywa finansowa na lata 2000-2006). Większe środki z budżetu ogólnego będą przeznaczone na zwiększenie konkurencyjności krajów członkowskich. Wspierane będą nowe cele strategiczne: 1) konwergencja - zmniejszanie dysproporcji pomiędzy biednymi a bogatymi regionami; 2) konkurencyjność regionalna i zatrudnienie oraz 3 ) europejska współpraca terytorialna. Założenia nowego okresu programowania stanowią próbę wyjścia naprzeciw nowym wyzwaniom, wynikającym ze zmian w gospodarce światowej i handlu międzynarodowym.

Grupy i wielkość wydatków w poszczególnych latach w ramach Perspektywy Finansowej 2007-2013 przedstawiono w tabeli $1^{55}$.

52 Commission of the European communities Brussels 26.2.2004 COM (2004) 101 final/2, źródło: http://eur-lex.europa.eu/LexUriServ/site/en/com/2004/com2004_0101en02.pdf.

53 M. Florio, Cost-benefitanalysis and incentivies in evaluation: the european structural funds 2007-2013, Northampton 2007.

54 Źródło: w http://eur-lex.europa.eu/LexUriServ/site/pl/oj/2006/c_139/c_13920060614p100010017.pdf; Dz. Urz. UE 2006/C 139/01.

${ }_{55}$ Źródło www.ukie.gov.pl. 
Tabela 1

\begin{tabular}{|c|c|c|c|c|c|c|c|c|}
\hline $\begin{array}{c}\text { Środki na } \\
\text { zobowiązania }\end{array}$ & $2007 *$ & $2008 *$ & $2009 *$ & $2010 *$ & $2011 *$ & $2012 *$ & 2013 * & $\begin{array}{l}\text { Ogółem } \\
\text { 2007-2013 }\end{array}$ \\
\hline 1. Trwały wzrost & 51267 & 52415 & 53616 & 54294 & 55368 & 56876 & 58303 & 382139 \\
\hline $\begin{array}{l}\text { la } \\
\text { Konkurencyjność na } \\
\text { rzecz wzrostu i za- } \\
\text { trudnienia }\end{array}$ & 8404 & 9097 & 9754 & 10434 & 11295 & 12153 & 12961 & 74098 \\
\hline $\begin{array}{l}1 \mathrm{~b} \\
\text { Spójność na rzecz } \\
\text { wzrostu i zatrudnienia }\end{array}$ & 42863 & 43318 & 43862 & 43860 & 44073 & 44723 & 45342 & 308041 \\
\hline $\begin{array}{l}\text { 2. Zarządzanie zaso- } \\
\text { bami naturalnymi i ich } \\
\text { ochrona }\end{array}$ & 54985 & 54322 & 53666 & 53035 & 52400 & 51775 & 51161 & 371344 \\
\hline $\begin{array}{l}\text { w tym: wydatki zwią- } \\
\text { zane z rynkiem i płat- } \\
\text { ności bezpośrednie }\end{array}$ & 43120 & 42697 & 42279 & 41864 & 41453 & 41047 & 40645 & 293105 \\
\hline $\begin{array}{l}\text { 3. Obywatelstwo, wol- } \\
\text { ność, bezpieczeństwo } \\
\text { i sprawiedliwość }\end{array}$ & 1199 & 1258 & 1380 & 1503 & 1645 & 1797 & 1988 & 10770 \\
\hline $\begin{array}{l}\text { 3a } \\
\text { Wolność, bezpieczeń- } \\
\text { stwo i sprawiedliwość }\end{array}$ & 600 & 690 & 790 & 910 & 1050 & 1200 & 1390 & 6630 \\
\hline $\begin{array}{l}3 \mathrm{~b} \\
\text { Obywatelstwo }\end{array}$ & 599 & 568 & 590 & 593 & 595 & 597 & 598 & 4140 \\
\hline $\begin{array}{l}\text { 4. UE jako partner } \\
\text { globalny }\end{array}$ & 6199 & 6469 & 6739 & 7009 & 7339 & 7679 & 8029 & 48463 \\
\hline 5. Administracja & 6633 & 6818 & 6973 & 7111 & 7255 & 7400 & 7610 & 49800 \\
\hline 6. Wyrównania & 419 & 191 & 190 & & & & & 800 \\
\hline $\begin{array}{l}\text { Środki na zobowiąza- } \\
\text { nia ogółem }\end{array}$ & 120702 & 121473 & 122564 & 122952 & 124007 & 125527 & 127091 & 864316 \\
\hline $\begin{array}{l}\text { Jako procent DNB } \\
\text { (dochodu narodowe- } \\
\text { go brutto) UE }\end{array}$ & $1,10 \%$ & $1,08 \%$ & $1,07 \%$ & $1,04 \%$ & $1,03 \%$ & $1,02 \%$ & $1,01 \%$ & $1,048 \%$ \\
\hline
\end{tabular}

* W mln euro - w cenach z 2004 r.

Źródło: Strona internetowa Ministerstwa Rozwoju Regionalnego www.mrr.gov.pl.

\section{Wnioski}

1. Specyfika finansowania działalności Unii Europejskiej oparta jest na scedowaniu przez kraje członkowskie na rzecz Wspólnoty wcześniej realizowanych przez siebie funkcji. Organizacja jako jedyna na świecie zasięgiem działalności oraz strukturą zaczyna „tworzyć" państwo federacyjne.

2. Wspólna realizacja przez państwa członkowskie celów finansowanych budżetem ogólnym Unii Europejskiej jest motorem rozwoju gospodarczego oraz wzmocnienia pozycji strategicznej Unii Europejskiej jako organizacji międzynarodowej.

3. Stosunkowo niewielki budżet, plasujący się średnio na poziomie $1,20 \%$ Produktu Narodowego Brutto całej Unii Europejskiej (około 100 mld euro rocznie) zapewnia 
zharmonizowany rozwój gospodarczy oraz zwiększa spójność ekonomiczną i społeczną wszystkich regionów Unii Europejskiej.

4. Stosowana w redystrybucji środków finansowych budżetu UE zasada solidarności i pomocniczości stwarza możliwość krajom członkowskim charakteryzującym się niedostatkiem ekonomicznym, zajęcia pozycji w organizacji jako tzw. „beneficjentów netto". Kraje otrzymują relatywnie więcej niż uiszczają do budżetu. Tworzy się szansa wyrównania wysokości PNB państw członkowskich i ustabilizowania rozwoju gospodarczego na równym poziomie we wszystkich regionach.

5. Stabilny system finansowy Unii Europejskiej oparty na zasadzie braku deficytu budżetowego, wieloletniego programowania, z precyzyjnie określonym procesem pozyskiwania i wydatkowania środków finansowych oraz w rezultacie odpowiedniej kontroli wykonania budżetu gwarantuje trwałość i stabilność organizacji.

6. Budżet europejski ma ważne znaczenie polityczne, ponieważ przy tworzeniu założeń finansowych istnieje konieczność dokonywania politycznych wyborów w kwestii alokacji i podziału zasobów pomiędzy kraje członkowskie, regiony oraz grupy społeczne w tych krajach.

7. Prowadzona polityka finansowa Unii Europejskiej kreuje realizację wspólnych polityk według jednakowych norm.

8. Państwa członkowskie w procesie kształtowania budżetów, adaptują założenia polityki fiskalnej UE, dostosowując je do założonych ram budżetowych.

9. Dostępność środków finansowych w ramach budżetu ogólnego jest uzależniona od stanowiska krajów członkowskich, w szczególności tych, które są płatnikami netto budżetu.

10. Dotychczasowe Perspektywy Finansowe okazały się skutecznym instrumentem dyscyplinowania wydatków z budżetu ogólnego.

11. Wieloletnie programowanie budżetu stwarza ramy finansowe dla urzeczywistnienia procesu rozszerzenia Unii Europejskiej o nowe kraje członkowskie.

12. System finansowy Unii Europejskiej stwarza możliwość harmonijnego włączenia ,nowych” krajów członkowskich do wszystkich wspólnych polityk oraz działań integracyjnych. 